\title{
Matrix Metalloproteinase-1 Inhibitor from the Aerial Parts of Viola ibukiana MAKINO
}

\author{
Hyung-In Moon, ${ }^{\star}$ Ji Eun Kim, Joongku Lee, ${ }^{\dagger}$ Ok-Pyo Zee,,$\underset{+}{*}$ and Jin Ho Chung \\ Department of Dermatologv, Seoul National Eniversity College of Medicine and Clinical Research Institute, \\ Seoul National Lniversity Hospital, Seoul 110-744, Korea. E-mail himunasnu.ackr; jhchungasnu.ac.kr \\ "Korea Research Institute of Bioscience and Biotechnologv, Daejeon 305-333, Korea \\ ${ }^{\ddagger}$ College of Pharmacy, Stung Kinn Kwan Linwersity, Sum $4+40-7+6$, Korea \\ Received December 29, 2004
}

Key Words : riola ibuthiana. Matrix metalloproteinase-1. Ultraviolet irradiation. Phenolic

Vola ibukiana (Violaceae) distributed in southern part of Korea. In traditional medicine. the herb has been used as an expectorant. a diuretic, and an antiinflammatory for bronchitis. rheumatism. skin eruptions. and eczema. ${ }^{1.2}$ Previous phytochenical studies on Viola species have revealed them to be a rich source of cyclotides. ${ }^{3,4}$ and several flavone glycosides. ${ }^{\ddagger 6}$ Although some common triterpene saponin has been reported. this plant has not been investigated in detail ${ }^{7}$ The matrix metalloproteinases (MMPs) are a family of $>20$ zinc-dependent endoproteinases that are capable of degrading almost all of the components of the extracellular matrix. ${ }^{8}$ MMPs can be divided into four categories based on substrate preference: collagenases, gelatinases. stromelysins. and membrane-associated matrix metalloproteinases. ${ }^{9}$ MMPs are necessary for tissue remodeling and the healing cascade under nomal physiological condition. The aging process of skin can be divided into intrinsic aging and photoaging. Clinically. naturally aged skin is smooth. pale. and finely wrinkled. In contrast, photoaged skin is coarsely wrinkled. ${ }^{11}$ Alterations in collagen. the major structural component of skin. have been suggested as a cause of the changes. such as skin wrinkling and loss of elasticity, which are observed in naturally aged and photoaged skin. ${ }^{11}$ With increasing age, collagen synthesis becomes lower and MMP-1 levels become higher in sun-protected human skin in vio. UV irradiation induces the synthesis of MMPs in fibroblast cell in vitro and MMP-mediated collagen destruction accounts, in large part. for the connective tissue dantage that occurs in photoaging. ${ }^{\prime c}$ In an ongoing investigation into MMP-1 inhibitory conpound from Viola ibukiana, a new active compound was isolated from the EtOAc soluble fraction. In this notes. we report on the constituent of Viola ibukiana, which inhibits UV-induced MMP-1 expression in hunan skin fibroblasts

\section{Experimental Section}

General Procedure. IR spectra were obtained with a
Perkin Elmer 1710 spectrophotometer. The NMR spectra was taken on a Bruker AMX $500\left({ }^{1} \mathrm{H} .500 \mathrm{MHz}:{ }^{13} \mathrm{C} .125\right.$ $\mathrm{MHz}$ ) spectrometer. FAB-MS spectra were obtained on a JMS AX505WA spectrometer. TLC was carried out on silica gel $60 \mathrm{~F}_{254}$ and RP-18 $\mathrm{F}_{254}$ plates (Merck. Germany). Column chromatography was performed over silica gel 60 (Merck, particle size 230-400 mesh) and Sephadex LH-20 (Pharmacia, Sweden).

Plant Material. The whole plants of Viola ibutiana (Violaceae) were collected in April 2004 at Ullung Island, Korea. The botanical identification was made by one of the authors. Dr. JoongKu Lee. A voucher specimen of this raw material has been deposited at the herbarium of the Seoul National University (SNU-04-04-15).

Extraction and Purification of Active Compound. The dried whole plants $(562 \mathrm{~g})$ of Vola ibukiana were extracted five times with $80 \% \mathrm{MeOH}$ in an ultrasonic apparatus for 3 hrs. This residue was evaporated in vacuo to yield the total extract $(48.7 \mathrm{~g})$. This extract was then suspended in distilled water and partitioned with $n$-hexane. $\mathrm{CHCl}_{3}$, EtOAc, and $n$ $\mathrm{BuOH}$. The EtOAc fraction $(7.8 \mathrm{~g})$ was subjected to silica gel column chromatography using $\mathrm{CHCl}_{3}$-EtOAc gradient system $(9: 1 \rightarrow 1: 1)$ to provide 11 fractions (fractions 1 i1). From fraction 8 , conpound 2 (16.3 $\mathrm{mg}$ ) was isolated using a silica gel column cluromatography $\left(\mathrm{CHCl}_{3}-\mathrm{EtOAc}\right.$, $20: 1$ ), and then purified by semipreparative RP-HPLC (YMC J'sphere- $\mathrm{H} 80,4 \mu \mathrm{m}, 250 \times 10 \mathrm{~mm}$. MeOH- $\mathrm{H}_{2} \mathrm{O}=$ $6: 4)$. Compounds $1(28.5 \mathrm{mg}$ ) was separated from fraction 9 by the same procedure as those of the fraction 8 .<smiles>O=c1c(-c2ccc(O)cc2O)coc2cc(O)cc(O)c12</smiles>

1<smiles>O=c1c(-c2ccc(O)cc2O)coc2cc(O)ccc12</smiles>

2
Figure 1. Structures of isolated compound from riola ibukiana. 
Primary Human Skin Fibroblasts Culture. Primary cultures of skin fibroblasts were established from human adult foreskins in Dulbecco's modified eagle medium (DMEM) supplenented with 10\% fetal calf serum. $2 \mathrm{mM}$ glutamine, and penicillin $(100 \mathrm{U} / \mathrm{ml})$, streptomycin $(100 \mathrm{mg} /$ $\mathrm{mL}$ ) in a $37^{\circ} \mathrm{C}$ hunidified incubator containing $5 \% \mathrm{CO}_{2}$. The fibroblasts were cultured until $90 \%$ confluency and then. subcultivated. Cells cultured after 5 passages were used for the experiments.

Cell Proliferation Assay and UV Irradiation Cell proliferation was determined by the MTT assay. ${ }^{12}$ which is based on reduction of soluble yellow MTT tetrazolium salt [3-(4,5-dimethylthiazol-2-yl)-2.5-diphenyl tetrazolium bromide] to a blue insoluble MTT formazan product by mitochondrial succinic dehydrogenase. After compound or UV treatment, the cells were cultured for indicated days: 20 $\mu \mathrm{L}$ of MTT $(5 \mathrm{mg} / \mathrm{mL})$ was added to each well. and the cells were incubated for $4 \mathrm{hrs}$ at $37^{\circ} \mathrm{C}$. The supernatant was removed. and $200 \mu \mathrm{L}$ of dimethylsulfoxide was added to each well to dissolve formazan products. The absorbance was determined spectrophotometrically at $570 \mathrm{rm}$ with an ELISA reader. The results were expressed as a percentage of control in six cultures. The UV light source was a $F 75 / 85 \mathrm{~W} /$ UV21 fluorescent sun lamps. having an enission spectrum between $285-350 \mathrm{lum}$ (peak at $310-315 \mathrm{lun}$ ) as previously described. ${ }^{7}$ A Kodacel filter (TA401/407; Kodak, Rochester. $\mathrm{NY}$ ) was mounted $2 \mathrm{~cm}$ in front of the UV tubes to remove wavelengths less than $290 \mathrm{~nm}$ (UV-C). The fibroblasts were grown in $10 \mathrm{~cm}$ culture dishes (Falcon, Lincoln Park. NJ) until subconfluent. Subsequently. the cells were cultured in serum-free medium for 24 hrs, and the medium was replaced by $2 \mathrm{~mL}$ of phosphate-buffered saline. Then the cells were exposed to UV $\left(0-100 \mathrm{~mJ} / \mathrm{cm}^{2}\right)$ light. After irradiation. the
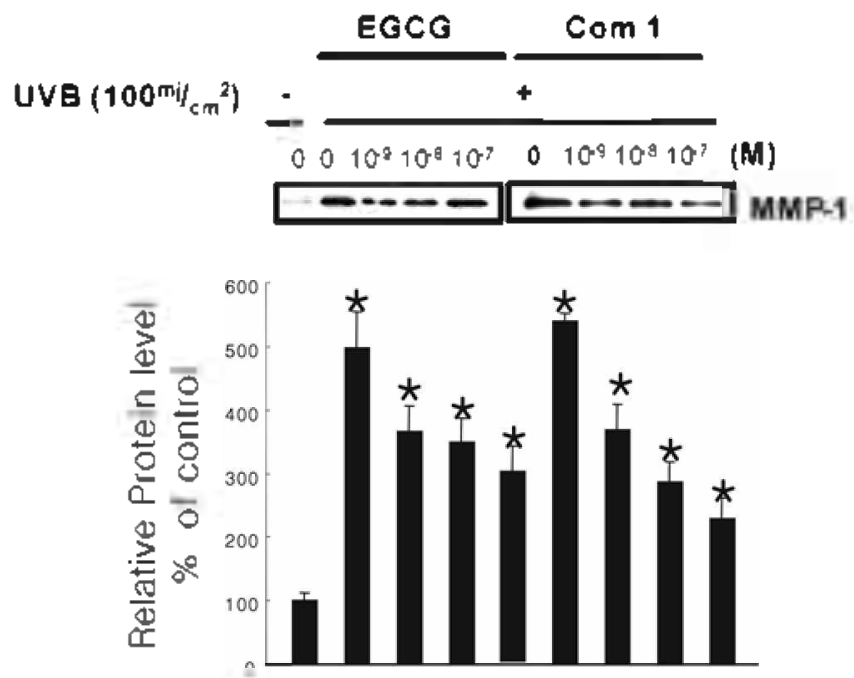

Figure 2. 2',4',5,7-tetrahydroxvisotlavone (1) prevents UV-induced increase in the MMP-l expression level in the culture human demal fibroblasts. The cells were pretreated with 2,4,5,7tetrahydroxvisoflavone (Com 1) prior to UV irradiation ( $100 \mathrm{~mJ} /$ $\mathrm{cm}^{2}$ ) and harvested $72 \mathrm{~h}$ later. Epigallocatechin-3-gallate (EGCG) was used as a positive control. Each value represents a mean \pm $\operatorname{SEM}(\mathrm{n}=5) .{ }^{*} p<0.05$ compared with the control. cells were washed with phosphate-buffered salme. and cultured in the media with or without compounds for the indicated time. ${ }^{13}$

Westeen Blots and Statistical Analysis. The supernatant was used for western blot analysis. A monoclonal antiMMP-I antibody (Oncogen. Co., Boston. MA. USA) were used as primary antibodies. Statistical significance was detemined using the Student t-tests. Results are presented by means \pm SEM. All $p$ values quoted are two-tailed and were accepted as significant when $p$ was $\leq 0.05$.

\section{Results and Discussion}

Phytochemical investigation of Vola ibukiana led to the isolation of five flavonoids from the EtOAc fraction using column chromatograply and HPLC. Compounds were identified as $2^{\prime} \cdot 4^{\prime} .5,7$-tetrahydroxylsoflavone (1). ${ }^{14 \cdot 15} 2^{\prime} \cdot 4^{\prime} .7$. trihydroxyisoflavone (2). ${ }^{[\text {-i.18 }}$ respectively, by comparing the NMR spectral data with those reported in the literature. Compounds have not been previously isolated from Viola ibukiana. We mvestigated the effects of 2'4',5.7-tetrahydroxyisoflavone on the expression of MMP-I in cultured human skin fibroblasts. The in vitro cytotoxicity assay was investigated according to reference. ${ }^{12}$ The compound did not show cytotoxicity against test doses $(0.1-10 \mu \mathrm{M} . \mathrm{p}<0.001)$. The expression levels of MMP-I protein were determined in culture media by westem blot analysis. We have demonstrated that compared with UV -treated cells (Fig. 2), the compound decreased the UV-induced expression of MMP-1 protein in a dose-dependent manner by an average of $73.1 \pm$ $6.2 \%(p<0.05 . \mathrm{n}=5)$ at $10^{-9}$ M. $62.4 \pm 3.5 \%(p<0.05 . \mathrm{n}=$ 5) at $10^{-8} \mu \mathrm{M}$, and $58.2 \pm 10.8 \%(p<0.05 . \mathrm{n}=5)$ at $10^{-7}$ $\mu \mathrm{M}$. The compound showed smilar activity to positive control. Epigallocatechin Gallate (EGCG) in the protein levels. In conclusion, 2'.4'.5,7-tetrahydroxyisoflavone may be used for the treatment and prevention of UV-induced expression of MMP-1 protem.

Acknowledgments. This study was supported by grant of the Korea Health 21 R\&D Project. Ministry of Health \& Welfare, Republic of Korea (03-PJI-PGl-CH14-0001).

\section{References}

1. Schuele, S.: Lederman. R. J. M fow Disord 2004, 19.43

2. Tennstedt D: Comphaut. P: Dooms-Goossens, A.: Lachapelle. J. M. Derm Benuf Lmotelt 1979.27.165.

3. Lindholm. H.: Goransson. U.: Tohansson. S.: Claeson. P.: Gullbo. J.: Larsson. R.: Bohlin1. L.: Backlund. A. Mol. Cancer Ther 2002. 1. 365 .

4. Svangard, E.: Goransson, U.: Smith. D.: Verma. C.: Backlund, A.: Bohlin, L.: Claeson. P. Plytochemistrv 1003. 64. 135.

5. Carnat, A. H.: Carnet, A.; Fraisse. D.: Lamaison, J. L.: Heitz. A.; Wylde. R.: Teulade. T. C.J. Nat. Prod 1998. 61. 272.

6. Xie. C.: Veitch. N. C.: Houghtn. P. J.: Simmonds. M. S. Chent Pharn. Bull. 2003. 51.1204.

7. Moon. H. I.; Chung, J. H.: Lee. J. K; Zee. O. P. Arch Pham Res 2004. 27,730

8. Chambers, A. F.: Matrisian, L. M. J. Natl. Cancer Inst. 1997,89. 1260 . 
9. Bernhard. E. J.: Gruber. S. B.: Muschel. R. J. Proc. Nat Acad. Sci. LS.A 1994. 91. 4293

10. Fisher. G. J.: Datta. S. C.: Talwar. H. S.: Wang. Z. Q.: Varani. J.: Kang, S.: Voorhees, J. J. Nature 1996. 379.335.

11. Varani. J: Wamer R. L.: Gharaee-Kermani. M: Phan, S. H.: Kang, S: Chung, J. H.: Wang. Z. Q.: Datta, S. C.: Fisher, G. I.: Voorhees. J. J. J. Invest Dermatol. 2000. 114.480.

12. Baek. S. H.: Oh. H. J.: Lim. J. A.: Chun. H. J.: Lee. H. O.: Alnn. J. W.: Perry. N. B.: Kim. H. M. Bull Eorean Chem. Soc. 2004. 25. 195.
13. Seo. I. Y: Lee. S. H.: Youn1. C. S.: Choi. H. R.: Rhie. G. E.: Cho. K. H.: Kinn. K. H.: Park. K. C.: Eun1. H. C.: Chung. T. H. J. Inest. Derntatol. 2001. 116.915.

14. Biggs. R. Atust. d. Chem. 1975, 28, 1389

15. Woodward, M. D. Phvtochemisoy 1985, 19,921.

16. Shirataki, Y.: Yokoe, I.: Komatsu. M. J. Nat. Prod. 1986. 49.645.

17. Kato. T.: Morita. Y. Chent. Pham Bull 1990. 38.2277.

18. Agrawal. P. K.: Bansal. M. C. Flanonoid Gheosides in Carbon-13 $M I R$ of Flononoids: Agrawal. P. K. Ed.: Elsevier: Amsterdam. 1989: $\mathrm{p} 283$ 